\title{
An Analysis of Behavioral Biases in Investment Decision-Making
}

\author{
Geetika Madaan $^{1} \&$ Sanjeet Singh ${ }^{1}$ \\ ${ }^{1}$ Chandigarh University, Mohali, Punjab, India \\ Correspondence: Geetika Madaan, Research Scholar, Chandigarh University, Mohali, Punjab, India.
}

Received: May 31, 2019

Accepted: June 25, 2019

Online Published: June 26, 2019

doi:10.5430/ijfr.v10n4p55

URL: https://doi.org/10.5430/ijfr.v10n4p55

\begin{abstract}
Individual investor's behavior is extensively influenced by various biases that highlighted in the growing discipline of behavior finance. Therefore, this study is also one of another effort to assess the impact of behavioral biases in investment decision-making in National Stock Exchange. A questionnaire is designed and through survey responses collected from 243 investors. The present research has applied inferential statistics and descriptive statistics. In the existing study, four behavioral biases have been reviewed namely, overconfidence, anchoring, disposition effect and herding behavior. The results show that overconfidence and herding bias have significant positive impact on investment decision. Overall results conclude that individual investors have limited knowledge and more prone towards making psychological errors. The findings of the study also indicate the existence of these four behavioral biases on individual investment decisions. This study will be helpful to financial intermediaries to advice their clients. Further, study can be elaborated to study other behavioral biases on investment decisions.
\end{abstract}

Keywords: behavioral biases, anchoring, disposition effect, overconfidence and individual investors

\section{Introduction}

The theory of rationality based on two assumptions, which are- "A rule of rationality" and "an act of rationality." In the situation of a rule of rationality, an individual adopts the mode of behavior that maximizes the expected utility whereas in case of an act of rationality investor chooses to act in such way that yields maximum utility. Investors make choices that maximize the benefits and minimize the cost (Ahmad Zamri, Ibrahim, Haslindar, Tuyon, 2017). Evidence and explanation proposed in the theory of bounded rationality explain that individuals are not always able to obtain all the relevant information, which is required to make possible decisions (Kinoshita, Suzuki, \& Shimokawa, 2013). Bounded rationality comprehensively concerned with the manner actual decision-making process impact the decisions that arrived (Kinoshita et al., 2013); (Ahmad Zamri, Ibrahim, Haslindar, Tuyon, 2017).

People are either partly rational or irrational in their decisions. This theory showed that individuals have biases and cognitive limitations, which forbid them from achieving full rationality at the time of decision-making (Ahmad Zamri, Ibrahim, Haslindar, Tuyon, 2017). When it comes to individual investment decision making, it is essential to consider that a certain degree of uncertainty and risk is associated with each investment decision choice (Paul Slovic, 1972). There is sufficient evidence, point out that due to the occurrence of market anomalies, markets react differently compared to the behavior of a rational man. Various cognitive biases often prevent individuals from rational thought. Individuals endowed with rationality that allows them to consider all the available information. From this, they develop unbiased forecasts about happening of future events, which allow them to make the best financial decisions (Fama, 1970); (Michael C. Jensen, 1978).

The foundation base of traditional finance is efficient market hypothesis. As per this hypothesis, investors have access to market information and prices of assets and also investors considered to be rational. Even though the discipline of modern finance has grown progressively, it is still difficult to explain on the scientific grounds that why people behave non- rationally while dealing in money. While traditional finance assumes people rationalize and enhance their financial decisions, behavior finance includes the relevance of what investors should do and blend the basics of traditional finance with what people do in terms of their investment decisions (Mitroi, Adrian Stancu, 2014). The domains of Psychology and sociology are considered to be imperative accelerators within the field of study of Behavioral Finance (Robert J. Shiller, 1997). In contradiction to the efficient market hypothesis, many studies have indicated behavioral biases in investors (Musciotto, Marotta, Piilo, \& Mantegna, 2018). The behavioral finance approach replaces the traditional rationality hypothesis and asserting that behavioral biases influence individuals. 
Behavioral Finance has seen as a study of how psychology influence financial markets and financial decision making (H. Shefrin, 2001). Behavioral finance is a new phenomenon to financial markets that have emerged in response to hurdles faced in traditional finance. It understood as a financial event where agents are not entirely rational (Barberis, 2002).

The father of Behavioral finance is 'Daniel Kahneman' who have received Nobel prize in the field of economics for his prospect theory. The pioneer researchers in the field of behavioral finance who's contributed tremendously are Daniel Kahneman, Amos Tversky, and Richard Thaler. They evolved behavioral biases that considered as building blocks of behavioral finance. Behavioral biases are critical issues for the contradictions between traditional finance and behavioral finance domains. There have been numerous studies that challenge rationality and thereby evolved Behavioral Finance (Tversky \& Kahneman, 1971). Behavioral biases provide reasons for the asymmetry between the way humans make decisions involving gains and decisions involving losses (Tversky, A \& Kahneman, 1973). The same individual who is a risk-averse for a decision involving gains becomes a risk seeker for a loss- avoiding decision (Tversky, A \& Kahneman, 1973). Overconfidence, herding, anchoring, cognitive dissonance, availability bias, self-attribution, mental accounting, framing, representative bias, are few biases that viewed as building blocks of behavioral finance that significantly influence the decision making of individual investor $(H$. M. Shefrin \& Thaler, 1988); (Singh, 2016).

Behavioral finance proposes that the investment decision -making process is influenced by various behavioral biases that boost investors to deviate from rationality and take irrational investment decisions (Niehaus \& Shrider, 2014). The present study is an extensive review of behavioral biases in individual investment decision-making (Taffler, Spence, \& Eshraghi, 2017). The relevance to this research field has increased recently, covering both theoretical and empirical contributions. After studying various literatures, it found that there is a need to conduct one study who carry systematic review on behavioral biases (Kumar \& Goyal, 2015). Here, in the present study, four different behavioral biases have been taken as a framework to study their impact on individual investment decision-making. This framework seems to reveal an intention to explore various behavioral biases through the lens of the discipline of behavioral finance.

These behavioral biases are:

- $\quad$ Overconfidence

- Anchoring

- Disposition effect

- Herding bias

\subsection{Overconfidence}

In behavioral finance, overconfidence is a psychological trait that has a substantial impact on individual investment decisions. Those decisions can be stock market investment decisions or other investment decisions (Joo, 2017). In behavioral finance, overconfidence mirrored as a common psychological bias, which makes financial markets inefficient by creating mispricing in the form of massive volatility and return variability (Ko \& James Huang, 2007). Many kinds of literature have mentioned the definition of overconfidence, but its definition better understood in following mentioned manner. Overconfidence is a psychological bias that directs an investor to think a parameter which is more significant than it is, and it also assumed that an individual's judgments are worsened and wrong. With those judgments, an individual would never learn the correct distribution (Dubra, 2004). During overconfidence, it observed that average mutual fund manager underperforms the market (Gruber, 1996).

Despite ample evidence that overconfidence is pervasive, it has not gained much attention in the field of economics. Much attention and broad applicability of overconfidence bias have found in the behavior of rational agents (Dubra, 2004). Researchers argue that overconfidence bias often directed by the neglect of unknowns (Walters, Fernbach, Fox, \& Sloman, 2016). It documented that increased overconfidence leads to excessive trading volume and higher price volatility in stock markets (Graham, Harvey, \& Huang, 2009); (Nir Jaimovich and Sergio Rebelo, 2007). Overreactions by investors are due to overconfidence about their abilities to grasp or process information (Kent Daniela, David Hirshleifer, 2002); (Mushinada \& Veluri, 2018). In contrary to this research, researchers argued that overconfidence is also a positive predictor that forecast the investment performance of individual investors that are followed by market anomalies (Abdin, Farooq, Sultana, \& Farooq, 2017). Therefore, Overconfidence is a judgmental error in which people overestimate their skill, knowledge, perceive information or expand the subjective probability of particular result happening (Campbell, Goodie, \& Foster, 2004); (Glaser, Markus and Weber, 2010).

\subsection{Herding Behavior}


Herding is a commonly observed phenomenon in the financial market. It is a common tendency of human nature to refer, observe, and imitate other's behavior during the irregular condition in financial markets (Yu, Dan, Ma, \& Jin, 2018). At the presence of herding, investors do not act rationally in their investment choices. They prefer to follow other investor's belief and opinions for taking their investment decision. Hence when investors herd, they tend to restrain their decisions and follow others. During times of market distress such as market anomalies, price bubbles, rumors, presence of herding effect is more profound (Mertzanis \& Allam, 2018). Herding has seen as collective imitation leading to a confluence of movements (Philippas, Economou, Babalos, \& Kostakis, 2013). It also showed in many research papers that herding behavior might result in similar patterns of movements across individuals realizing substantial welfare losses. In one of the research papers, herd behavior has defined in a different way that is if agents are granted to approach the strategies of their network neighbors, a feedback effect on the network structure and game outputs observed. Such an effect termed as herding behavior (Mello, Souza, Cajueiro, \& Andrade, 2010). When some agents are prepared to pursue their wealthiest neighbors instinctively, a new type of corporate event, called herding behavior, may arise (Mello et al., 2010).

\subsection{Anchoring}

Anchoring is one of the most researched psychological biases (Shin \& Park, 2018). Anchoring bias effect investor's decision-making processes (Wright \& Anderson, 1989). Anchoring defined as a cognitive bias that explains the ordinary human being's tendency to depend massively on the first piece of information while making decisions (Shin \& Park, 2018); (Maqsood Ahmad, Syed Zulfiqar Ali Shah, 2018); (Singh, 2016). Investors are likely to anchor their purchases of stocks on the recent highest price of the stock. Such behavioral reactions show that anchoring bias associated with suboptimal decisions of investors in their decision-making processes (Krause, Shiller, Shleifer, Wilcox, $\&$ Shiller, 1970). Anchoring bias shows as a criterion to analyze stock returns or profitability by a behavioral approach at uncertain circumstances in 52- week high and momentum strategies (Jahanmiri, 2018). Researchers documents that anchoring lays a negative impact on investment decisions made by individual investors or traders (Maqsood Ahmad, Syed Zulfiqar Ali Shah, 2018). Researchers also argue that Anchoring as a judgmental bias, final judgments when to comprehend toward the starting point of the judge's consideration. The anchoring-and-adjustment heuristic holds that anchoring bias caused by insufficient adjustment (Qu, Zhou, \& Luo, 2008). The anchoring heuristic holds to abundant moderation that is underreaction. People anchor at some noticeable results, during using this heuristic and conform based on predictive information (Amir \& Ganzach, 1998). Therefore, anchoring is a heuristic bias that causes investors to rely on recent price changes and price levels (Ormos \& Timotity, 2016).

\subsection{Disposition Effect}

The disposition effect is the propensity of investors to refrain from realized loss in expectations of realized gains (Pelster \& Hofmann, 2018). The disposition effect estimated as the difference between the fraction of realized gains and the fraction of realized losses (Odean, 1999); (Odean, Strahilevitz, \& Barber, 2010). Researchers have recognized that the tendency of investors to hold losses in investment to prolong and sell winners in investment too early has marked as disposition effect. The disposition effect has adverse outcomes on an individual's investment because losing investments commonly carry on to underperform, whereas winning investments usually carry on to outperform (Aspara \& Hoffmann, 2015). Researchers have recognized that the disposition effect is not affected by experimental manipulations of expected future gains or losses (H.-J. Lee, Park, Lee, \& Wyer, 2008).

\section{Review of Literature}

Even though the discipline of modern finance has proliferated, it is still difficult to explain on scientific grounds why people behave irrationally while dealing with money (Smit \& Moraitis, 2010); (Mitroi, Adrian Stancu, 2014). The behavioral approach is a new approach to explain the movement in financial markets, which is contrary to the efficient market hypothesis. Traditional finance believed that security prices always completely mirrored the available information (Fama, 1970) whereas behavioral finance states that due to non-rational behavior of investors and inefficiency of financial markets stock or security prices deviate (Cabral de Avila, Lucimar Antonio de Oliveira, Alanna Santos de Melo Silva Avila, Jessica Rayse Malaquias, 2016); (Kabasinskas \& Macys, 2010). With the increased involvement of investors, behavioral finance focuses on investor behavior and their investment decision-making process (Liu, Jin, Wang, \& Yuan, 2015). Overconfidence is one of the primary building blocks in the discipline of behavioral finance. Overconfidence is a vigorous outcome of psychology, which studied as one of the principal reasons for market anomalies (Ko \& James Huang, 2007). Overconfidence is a well-established bias that makes investors too confident about their knowledge and skills and ignores the risk linked to investment decisions (Prosad, Kapoor, Sengupta, \& Roychoudhary, 2018); (Kamoto, 2014). Confidence explained as complete faith in oneself. While dealing with securities, when an investor is much confident about his strategies and mental tendency, 
then, in that case, the investor is influenced of overconfidence bias (Huang, Tan, \& Zhong, 2014). In the circumstances of overconfidence, the investor may take the happening of events for granted, which may or may not due to dynamic economic conditions. Prevalent contributors to the discipline of overconfidence bias are Kahneman, Tversky, Shiller, Shefrin, Barber, and Odean. The impact of behavioral baizes in investment decision making drawn from trading volumes of stock markets. Overconfidence behavior can lead to higher trading volumes (Darrat, Zhong, \& Cheng, 2007); (Phan, Rieger, \& Wang, 2018); (Mushinada \& Veluri, 2018); (Khan, Tan, Chong, \& Ong, 2017). Advice driven or gambling oriented study has been undertaken where structured retail products that are faces of financial innovation have been taken for study. Findings of the study indicated that structured retail products are comprehensively connected to investor's behavioural biases particularly overconfidence (Abreu \& Mendes, 2018)

The research was investigated to study the influence of past behavior or belief on, and it found that anchoring bias attitude on belief represents the inconsistent result. It further investigated that individuals resolve conflicts between their resultant belief and past behavior by adjusting anchoring attitudes with beliefs instead of behavior. It further supported the interpretation that individuals resolve the conflict between past behavior and subsequent beliefs about it by aligning attitudes with beliefs instead of behavior. On anchoring bias, a study has been conducted to investigate the effects of anchoring on stock return estimates by using data from surveys involving university students and financial market professionals. The background information given to subjects also manipulated. It also observed that the assessment of university students influenced by initial starting value of the stock and in case of professionals' assessment was not statistically and economically significant and also professionals are not conscious of the influence of historical returns based on their expectations (Kaustia, Alho, \& Puttonen, 2008). By applying an event-related potential experiment on young, healthy subjects, the impact of hidden anchoring effects studied that generated by false information on numerical judgements. The effect of anchoring on investors' estimates of returns earned in unit trust has been studied in investing environment in which subjects were invested and assessed that subjects would adjust their estimates subsequently presented with an anchor. Study resulted presence of an anchor appeared to have no effect on respondents 'assessments (Dowie \& Willows, 2016)' To explore trading strategies that exploit investor's behavioral anchoring bias, a study was investigated where anchoring was studied both from technical signal and anomalies point of view. In study empirical evidence indicated that anchoring bias explains the profitability as a broad set of anomalies and describes trading strategies that exploit the anchoring bias (Qingzhong Ma, Hui Wang, 2017).

The behavioural results indicated that false information comprehends final assessments having a direct relationship that is higher subsequent higher anchors and lower subsequent lower anchors. In comparison to uncertain information, false information induces a fragile anchoring bias (Qu et al., 2008). Anchoring behavior also induced by an empirical assessment of price anchoring in online markets. The research explored that uninformative information impact choices of investment decision, particularly the anchoring effect found in bidding for online auctions. Results of the study confirmed the existence of anchoring behavioral bias in an online auction.

To understand the bias of disposition effect on individual investment decision making, the effect of disposition on the underlying mechanism of e-trading of stocks has investigated by researchers in their study. It appeared in the study that disposition has at times, negative financial effect. In recently emerged internet-based e-trading situation, disposition effect is not affected by the possibility of prospective gains or losses (H.-J. Lee et al., 2008). The existence of Disposition effect in investors of Taiwanese warrant markets assessed in a study. Empirical results of the research indicated that the presence of disposition effect in Taiwanese warrant markets, and further, it also indicated that warrants with different market price displayed different disposition behavior (Chang, 2008). To investigate the influence of disposition effect on the investment decision making in an emerging Chinese stock market, the researchers used the brokerage account data from China and found that Chinese investors made bad off trading decisions and recognized gains but not losses. They incline to sell those stocks that have increased in price but not those stocks that have decreased in price that displayed persistent disposition behavior (Gongmeng Chen, Kenneth A. Kim, 2007).

Further analyzing disposition effect, a paper investigated the effect in trading records of a discount brokerage house. By applying socio-economic and demographic factors, empirical evidence has found that wealthier investors and professional investors displayed a lower disposition effect (Dhar \& Zhu, 2006). Empirical evidence was appeared to study the market-wide impact of disposition effect on trading volume of Initial Public Offer and disposition effect was found to be at its most reliable due to current purchase price initiated by investors in Initial Public Offer (Kaustia, 2004). Similar to this IPO study, another research exists that investigated the aftermarket effect of disposition on IPO in Bursa Malaysia market. This study indicated that 2.64 times more investors intended to flip a winning IPO in comparison to losing IPO that result in consistent disposition effect (Chong, 2009). The role of disposition has studied in equity premium. Paper showed that the existence of disposition effect by investors tend investors to bear higher risk premiums for investing in stocks (Roger, 2009). Research has examined the disposition effect in the investment 
performance in the Korean stock index futures market and provided strong evidence of the existence of disposition effect in the investment performance. It found in the study that individual investors are more prone towards disposition effect than foreign and institutional investors.

Moreover, there is a negative relationship between investment performance and disposition effect, and also disposition bias is stronger in long positions than in short position. In support of this research, another study has been conducted to study the effects of disposition on individual investors in the Taiwan Stock Market. Results of this research indicated that the level of education of individual investors has a positive relationship with the disposition effect. The role of disposition effect has been studied in Taiwan mutual fund investors. The result indicated that disposition effect varies across market states. Disposition effect was not found uniform in Taiwan mutual fund investors. Results suggested that during bear market investors redeem their mutual funds more in comparison to bull market. Therefore, in the research, it was found that the phenomenon of disposition effect presents for Taiwan mutual fund investors also (J. S. Lee, Yen, \& Chan, 2013)

To study the impact of herding bias on individual investment decision making, an alternative approach was proposed to assess an asymmetric risk-return relationship in financial markets with having the involvement of herding behavior. Results of the study indicated inverse feedback found in Asian financial markets as a consequence of the herding phenomenon (Bekiros, Jlassi, Lucey, Naoui, \& Uddin, 2017). In one of the studies herding behavior of Muslims in Islamic banking and finance has been studied. The study revealed the existence of herding behavior as the first-order factor. Research has conducted where the impact of herding examined on the firm's business cycle. Findings of the study suggested that the aggregated pattern of herding illuminated in a firm's business cycle (Mueller \& Brettel, 2012). On the contrary, evidence was obtained when it comes to herding effect at times when markets were highly volatile, that Exchange traded funds' return dispersion decreases due to excessively intraday volatility (Rompotis, 2018).

One of the studies examined how herding behavior is related to rational decision making among individuals. The results of the study implied the existence of herding behavior in individual investment decision making. Also, further in the study, it was demonstrated that herding bias is different in the case of male and female (Lin, 2011). One of the researches contributed towards the understanding of the impact of herding behavior on property investment decisions taken in a highly volatile environment. The study suggested that herding behavior may exist in the decisions made by property fund managers (Hall, 2016). Experimental research examined the impact of herding behavior on diversification behavior. Results suggested that herding behavior significantly influence nonoptimal portfolio choices (Filiz, Nahmer, Spiwoks, \& Bizer, 2018). In one of the research influences of herding behavior was examined on institutional investor attributing this behavior to consider same published information and thereby safeguarding investors reputation and career. A role of herding behavior of mutual fund managers examined, and it analyzed that herding behavior influenced by paper gain ratio and paper loss ratio. It also found that, but herding behavior of mutual fund manager harms investment performance.

Moreover, in sell effect of herding behavior disappeared. It further found that even disposition effect also influences herding bias as well. The presence of the herding effect more profound in Asian markets, their herding asymmetry during rising markets have witnessed. Moreover, during the global crisis as well herding presence was found in the US and Latin American markets. It was appeared in research that bank's herding diverges with different types of loans. It was showed in paper that herding was more frequently found in housing loans and credit cards than other types of loans. Moreover, it was also examined in the paper that big banks herd more in comparison to smaller and regional banks (Tran, Nguyen, \& Lin, 2017). In one of the studies herding behaviour presence was investigated between stock market and oil market during market distress. Researchers found that herding behaviour reduced due to the volatility of the stock market. It was also examined and occurred that herding behaviour moved inversely in both the markets and herding behaviour is further enhanced by unavailability of information in both the markets (Ben Mabrouk, 2018).

However, review of previous studies indicates that many behavioral biases are overlapping or expansion of other behavioral biases. This study considers only four biases which frequently observed in investment decision-making. The above-cited previous studies support the fact that behavioral biases have a significant impact on investment-decision making. There are studies like Paul Slovic (1972) that claimed that behavioral biases have a significant relationship with investors type. Fundamentally, Every investor influenced by different behavioral biases. Therefore, different investors make investment decisions differently. The present research made an effort to overcome the gaps found in literature and thereby analyze the impact of four behavior biases on investor's decision making.

The following is the conceptual framework, and that can draw from the above literature review: 

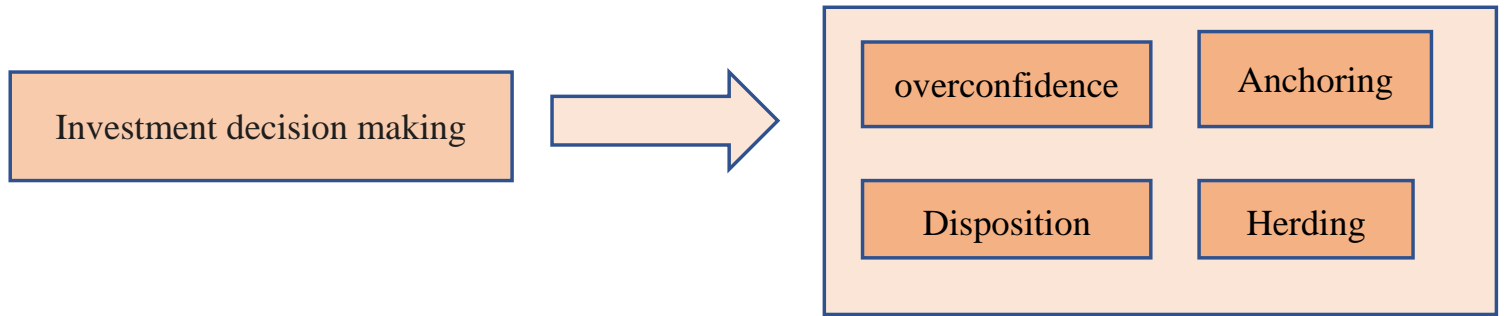

Figure 1. Conceptual framework

Research hypothesis can draw from the above literature review:

$\mathrm{H}_{\mathrm{a} 1}$ : there is a significant relationship between behavioral biases and investment decision- making.

$\mathrm{Ha}$ 2: overconfidence is significantly influenced by investment decision- making.

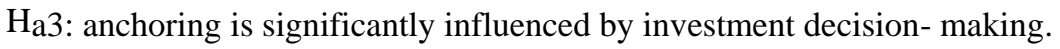

$\mathrm{H}_{\mathrm{a}} 4$ : disposition is significantly influenced by investment decision- making.

$\mathrm{H}_{\mathrm{a}}$ : herding is significantly influenced by investment decision- making.

\section{Research Methodology}

The present study is a cross-sectional study and Quantitative method used for data analysis. A questionnaire designed and survey method is applied to obtain responses. The actual sample size for the study was 385, but few questionnaires found not adequately filled. Therefore, only 243 questionnaires were found useful and selected as sample size. Convenience sampling technique is used to collect data from investors in National Stock Exchange. The purpose of this research analysis is to interpret and draw a conclusion from the collected data. Inferential statistics, as well as descriptive statistics, are applied for data analysis. Spss software used for statistical computation. Firstly, Cronbach Alpha is applied to check the reliability of data. The range from $0.70-0.90$ is considered to be acceptable. Secondly, the correlation coefficient is carried out to test the relationship among variables that is investment decision making and behavioral biases. Then, finally, regression analysis is conducted to identify the impact among variables.

\section{Results}

This chapter comprised of results and interpretation of the data. First, the Cronbach's alpha test for measurement of reliability done. Secondly, the correlation coefficient among the behavioral biases and investment decision making is studied. The results of the reliability test (Table 1) indicated that the value of Cronbach Alpha is 0.762. Therefore, the scale is reliable as the value of Cronbach alpha is more significant than 0.6.

Table 1. Reliability statistics

\begin{tabular}{lll}
\hline Cronbach's Alpha & Cronbach's Alpha Based on Standardized Items & N of Items \\
\hline 0.762 & 0.740 & 5 \\
\hline
\end{tabular}

Table 2. Investor's demographic profile

\begin{tabular}{lll}
\hline Demographic Components & Frequency & Percentage \\
\hline Age & & \\
\hline $18-25$ & 84 & 35.8 \\
\hline $25-30$ & 73 & 28.4 \\
\hline $30-35$ & 17 & 7.5 \\
\hline Above 35 & 77 & 26.8 \\
\hline Gender & & 85.9 \\
\hline Male & 207 & 11.8
\end{tabular}




\begin{tabular}{lll}
\hline Level of Education & 58 & \\
\hline Undergraduate & 84 & 25.8 \\
\hline Graduate & 88 & 34.5 \\
\hline Postgraduate & 7 & 38.7 \\
\hline Other & 127 & \\
\hline Profession & 114 & 52.8 \\
\hline Business & & 49.2 \\
\hline Salaried & 89 & \\
\hline Experience & 30 & 38.2 \\
\hline Under 5 years & 45 & 13.1 \\
\hline $6-7$ years & 40 & 17.8 \\
\hline $8-10$ years & 33 & 16.7 \\
\hline $11-15$ years & & 13.2
\end{tabular}

\subsection{Correlation Analysis}

Table 3. Results of correlation

\begin{tabular}{|c|c|c|c|c|c|c|}
\hline & & $\begin{array}{l}\text { Investment } \\
\text { Decision Making }\end{array}$ & Overconfidence & Anchoring & Disposition & Herding \\
\hline \multirow{3}{*}{$\begin{array}{l}\text { Investment } \\
\text { Decision } \\
\text { Making }\end{array}$} & $\begin{array}{l}\text { Pearson } \\
\text { Correlation }\end{array}$ & 1 & $0.409^{* *}$ & $0.378^{* *}$ & $0.325^{* *}$ & $0.402^{* *}$ \\
\hline & $\overline{\text { Sig. (2-tailed) }}$ & & 0.000 & 0.000 & 0.000 & 0.000 \\
\hline & $\mathrm{N}$ & 251 & 251 & 251 & 244 & 238 \\
\hline \multirow{3}{*}{ Over- confidence } & $\begin{array}{l}\text { Pearson } \\
\text { Correlation }\end{array}$ & $0.409^{* *}$ & 1 & $0.498^{* *}$ & $0.541^{* *}$ & $0.463^{* *}$ \\
\hline & Sig. (2-tailed) & 0.000 & & 0.000 & 0.000 & 0.000 \\
\hline & $\mathrm{N}$ & 251 & 251 & 251 & 244 & 238 \\
\hline \multirow{4}{*}{ Anchoring } & Pearson & $0.378^{* *}$ & $0.498^{* *}$ & 1 & $0.614^{* *}$ & $0.604^{* *}$ \\
\hline & Correlation & & & & & \\
\hline & Sig. (2-tailed) & 0.000 & 0.000 & & 0.000 & 0.000 \\
\hline & $\overline{\mathrm{N}}$ & 251 & 251 & 251 & 244 & 238 \\
\hline \multirow{4}{*}{ Disposition } & Pearson & $0.325^{* *}$ & $0.541^{* *}$ & $0.614^{* *}$ & 1 & $0.523^{* *}$ \\
\hline & Correlation & & & & & \\
\hline & Sig. (2-tailed) & 0.000 & 0.000 & 0.000 & & 0.000 \\
\hline & $\mathrm{N}$ & 244 & 244 & 244 & 244 & 238 \\
\hline \multirow{3}{*}{ Herding } & $\begin{array}{l}\text { Pearson } \\
\text { Correlation }\end{array}$ & $0.402 * *$ & $0.463 * *$ & $0.604 * *$ & $0.523 * *$ & \\
\hline & Sig. (2-tailed) & 0.000 & 0.000 & 0.000 & 0.000 & 1 \\
\hline & $\mathrm{N}$ & 238 & 238 & 238 & 232 & \\
\hline
\end{tabular}

**. Correlation is significant at the 0.01 level (2-tailed)

From the analysis of the relationship among variables (table 3), it found that all the variables have a strong relationship 
with each other. There is a positive relationship between investment decision-making and overconfidence variables, that is 0.409 at $1 \%$ level of certainty. This shows that if the overconfidence of investor increases, the investor's decision making for investment also increases. The degree of relationship between Anchoring bias and investment decision making is 0.378 , which is critical at a $1 \%$ level of certainty. This expresses that there is a significant positive relationship between Anchoring bias and investment decision making variable, and when anchoring increases, then investment decision making also rises. The connection between disposition bias and investment decision making also significantly positive, which is 0.325 noteworthy at $1 \%$ level of certainty. This expresses that investment decision making also increases with increase in disposition bias also. The degree of relationship among herding bias and investment decision making is 0.402 at $1 \%$ level of certainty which shows that there is a positive relationship among these two variables and if herding bias increases then investor make investment decisions accordingly.

\subsection{Regression Analysis}

Table 4. Regression analysis

\begin{tabular}{lllll}
\hline Model & R & R Square & Adjusted R Square & Std. Error of the Estimate \\
\hline 1 & $0.477^{\mathrm{a}}$ & 0.235 & 0.218 & 0.6582 \\
\hline
\end{tabular}

Predictors: herding, overconfidence, disposition, anchoring

The analysis mentioned above (table 4) shows the results of linear regression. Investment decision-making considered as the dependent variable and four independent variables considered for the study, i.e., Overconfidence, anchoring, disposition, and herding bias. To assess the model fitness, the results of the model summary evaluated. The model summary indicates that R Square shows 0.235 variations in investment decision making is explained by the model, while adjusted $\mathrm{R}$ squared is 0.218 , which is close to $\mathrm{r}$ squared. A reliable model indicated because of the high value of $\mathrm{R}$. The results show $23.5 \%$ of predictability level, which is low. However, this may be because of the other variables not considered in this model.

\subsection{Overall and Individual Difference}

The below mentioned F-statistics (Table 5) shows the overall fitness of the model, and it can be analyzed that the model is overall fit as its p-value (sig.) is less than 0.05 .

Table 5. Overall significance

\begin{tabular}{l}
\hline F \\
$\begin{array}{l}13.889 \\
0.000^{\mathrm{b}}\end{array}$ \\
\hline a. Dependent Variable: Investment decision-making \\
\hline b. Predictors: (Constant), herding, overconfidence, disposition, anchoring \\
\hline
\end{tabular}

Table 6. Individual significance

\begin{tabular}{llllll}
\hline Model & \multicolumn{2}{l}{ Unstandardized coefficients } & $\begin{array}{l}\text { Standardized } \\
\text { coefficients }\end{array}$ & T & Sig. \\
\hline & B & Std. Error & Beta & & \\
\hline (Constant) & 1.836 & 0.245 & & 7.687 & 0.000 \\
\hline Over-confidence & 0.270 & 0.071 & 0.293 & 3.759 & 0.000 \\
\hline Anchoring & 0.137 & 0.081 & 0.146 & 1.736 & 0.085 \\
\hline Disposition & 0.038 & 0.071 & 0.045 & 0.561 & 0.575 \\
\hline Herding & 0.194 & 0.074 & 0.201 & 2.561 & 0.012 \\
\hline
\end{tabular}


The results mentioned above (table 6) show individual significance test, which depicts that overconfidence and herding bias have a significant influence on the investment decision-making of an investor as their significance values are less than 0.05 . The remaining variables i.e., anchoring and disposition biases have significance value higher than 0.05 , indicating that disposition bias and anchoring bias, do not have any influence on investment decision-making of investors.

\section{Discussion}

While dealing with different investment options, there is one fundamental question people face that what is the best plan of action for investing in the financial instruments and to what magnitude can the historical price movements in the stock market can be used to forecast of the future price movements? Based on the assumption of rationality, it appeared that investors would choose those financial instruments that maximize gains and minimize losses (Ahmad Zamri, Ibrahim, Haslindar, Tuyon, 2017). People are considered partly rational and irrational in their investment behavior. Behavioral finance studied the irrational aspect of human as an investor in their investment decision process. This branch of discipline indicated that cognitive biases prevent investors from realizing a complete sense of rationality at the time of investment decision-making. An act of rationality linked with a magnitude of uncertainty and risk, which is associated with every investment decision option (Paul Slovic, 1972). Various behavioral biases influence these risk and uncertainty. These behavioral biases focus on investor's behavior and their investment decision-making process. Behavioral biases are considered to be building blocks of behavioral finance that combine individual behavior and market phenomenon. In behavioral finance domain, various biases exist. For the present research, four biases have considered for a study that is overconfidence, anchoring, disposition effect, and herding bias.

After studying research papers on various behavioral biases, it documented that most of the financial and economic theories displayed that individuals behave rationally in the process of investment decision making only when they have all available relevant information. When information is not fully available to them in that case, empirical evidence indicated repeated patterns of irrationality that appeared like the way individual investors arrive at decisions and choices when confronted with risk and uncertainty. The four common behavioral biases also documented that their presence exists in the stock market or portfolio selection during decision making. Their presence leads to excessive trading volume and results in higher transaction cost. The present study also throws light on market psychology whereby it indicated that investors buy or sell stocks and why sometimes they do not buy or sell at all hence, the most critical challenge faced by investors is in the field of investment decisions. It reflected in the present study that the gains and losses realized by investors mainly depend on his investment decision-making competences. It observed that in the present scenario, investment decision-making process needs a better understanding of individual investor's behavioral biases as the existence of these behavioral biases have also been found both before and during the global financial crisis as well. The focus in the present study was on individual investors as they found to have limited knowledge about the application of conventional finance theories in decision making and hence more inclined towards making psychological errors. The result of our study shows that from four independent variables only two variables namely Overconfidence and herding bias have a significant impact on investment decision making with t-values of $3.759,2.561$ respectively while other variables namely disposition and anchoring have no significant impact on investment decision making. The present study was focussed on mainly formulation and analysis of four behavioral bias, namely, anchoring, overconfidence, disposition effect, and herding behavior. In future study can be elaborated by analyzing other behavioral biases that too have a substantial impact on individual investment decision making in their unique way. Moreover, the study can also further be elaborated to investigate the impact on a group or corporate investment decision making as well.

\section{Conclusion}

The discipline of behavioral finance has emerged in response to handle the difficulties faced by the traditional finance discipline. In essence, behavioral finance explains that investment choices not always influenced based on rationality. Behavioral finance also tried to understand the investment market anomalies by unwinding the two assumptions of standard finance, that is, (i) investors fail to update their beliefs precisely and (ii) there is a systematic variation from the normative process in making investment choices (Kishore, 2004).

In the 1960s, Kahneman and Tversky concentrated on different fields of research. After the energy crisis of the 1970s, they came together and conducted research and found inconsistent results with the Efficient Market Hypothesis and Expected Utility theory (Daniel Kahneman and Amos Tversky, 1979). In the 1980s, behavioral finance has emerged as an alternative perspective that combined the behavioral and psychological aspects in economic and financial decision-making or in another way we can understand that this field of behavioral finance provides behavioral and psychological explanations (Abay, Blalock, \& Berhane, 2017). Scientific work on the normative theory by Tversky 
and Kahneman's 'psychophysical emphasis on the difference between objective stimulus and subjective sensation' combined precisely to suffice the motive (Heukelom, 2007). Behavioral finance helps the academicians, economists, and researchers to study financial markets in complex and uncertain circumstances (Shleifer, 2000).

To understand the irrational behavior of investors in financial markets, researchers draw on knowledge from cognitive psychology theories. Researchers have developed "prospect theory" and "heuristics" to explain the behavior of individual investors in financial or economic decisions. Behavioral finance involves various behavioral biases based on an individual's social and emotional recognition and tolerance. The present study aims to determine the influence of behavioral biases on investment decision making of individuals. Mainly four behavioral biases are taken into current research for identification of impact, namely, Overconfidence, Anchoring, disposition effect, and Herding. The study concluded that two, namely overconfidence and herding, have a strong influence on the investment decisions of individuals. The current research also emphasized that participants in financial markets are not rational in their decision-making process, and even their choices are limited.

In the present study, the analysis and discussion brought forward many issues for further research. In the future, investigations can be performed to study other biases that are not included in the present study this time. Also, the impact of decisions of individuals and institutions can be reviewed on mutual funds as well.

\section{References}

Abay, K. A., Blalock, G., \& Berhane, G. (2017). Locus of control and technology adoption in developing country agriculture: Evidence from Ethiopia. Journal of Economic Behavior and Organization, 143, 98-115. https://doi.org/10.1016/j.jebo.2017.09.012

Abdin, S. Z. ul., Farooq, O., Sultana, N., \& Farooq, M. (2017). The impact of heuristics on investment decision and performance: Exploring multiple mediation mechanisms. Research in International Business and Finance, 42, 674-688. https://doi.org/10.1016/j.ribaf.2017.07.010

Abreu, M., \& Mendes, V. (2018). The investor in structured retail products: Advice driven or gambling oriented?. Journal of Behavioral and Experimental Finance, 17, 1-9. https://doi.org/10.1016/j.jbef.2017.12.001

Ahmad, M., Shah, S. Z. A., \& Mahmood, F. (2018). Qualitative Research in Financial Markets. Asian Review of Accounting, 18(1). https://doi.org/10.1108/ara.2010.34118aaa.002

Amir, E., \& Ganzach, Y. (1998). Overreaction and underreaction in analysts' forecasts. Journal of Economic Behavior \& Organization, 37(3), 333-347. https://doi.org/10.1016/S0167-2681(98)00092-4

Aspara, J., \& Hoffmann, A. O. I. (2015). Selling losers and keeping winners: How (savings) goal dynamics predict a reversal of the disposition effect. Marketing Letters, 26(2), 201-211. https://doi.org/10.1007/s11002-013-9275-9

Barberis, N. (2002, September). A Survey of Behavioral Finance. Journal Bureau of Economic Research. https://doi.org/10.1002/rra

Bekiros, S., Jlassi, M., Lucey, B., Naoui, K., \& Uddin, G. S. (2017). Herding behavior, market sentiment and volatility: Will the bubble resume?. North American Journal of Economics and Finance, 42, 107-131. https://doi.org/10.1016/j.najef.2017.07.005

BenMabrouk, H. (2018). Cross-herding behavior between the stock market and the crude oil market during financial distress: Evidence from the New York stock exchange. Managerial Finance, 44(4), 439-458. https://doi.org/10.1108/MF-09-2017-0363

Campbell, W. K., Goodie, A. S., \& Foster, J. D. (2004). Narcissism , Confidence, and Risk Attitude. Journal of Behavioral Decision Making, 311, 297-311.

Chang, C.-H. (2008). The Impact of Behavioral Pitfalls on Investors' Decisions: the Disposition Effect in the Taiwanese Warrant Market. Social Behavior and Personality: An International Journal, 36(5), 617-634. https://doi.org/10.7748/nm2013.06.20.3.7.s9

Chen, G. M., Kim, K. A., Nofsinger, J. R., \& Rui, O. M. (2007). Trading Performance, Disposition Effect, Overconfidence, Representativeness Bias, and Experience of Emerging Market Investors. Journal of Behavioral Decision Making, 2(4), 425-451. https://doi.org/10.1002/bdm

Chong, F. (2009). Disposition Effect and Flippers in the Bursa Malaysia. Journal of Behavioral Finance, 10(3), 152-157. https://doi.org/10.1080/15427560903167712

Daniela, K., Hirshleifer, D., \& Teoh, S. H. (2002). Investor psychology in capital markets: evidence and policy implications. Journal of Monetary Economics, 49, 139-209. https://doi.org/10.1007/978-3-642-39371-6-36 
Darrat, A. F., Zhong, M., \& Cheng, L. T. W. (2007). Intraday volume and volatility relations with and without public news. Journal of Banking and Finance, 31(9), 2711-2729. https://doi.org/10.1016/j.jbankfin.2006.11.019

de Avila, C., de Oliveira, L. A., de Melo Silva Avila, A. S., \& Jessica Rayse Malaquias, R. F. (2016). Behavioral Biases in Investors' Decision: Studies Review From 2006-2015. Revista De Gestao Financas E Contabilidade.

Dhar, R., \& Zhu, N. (2006). Up Close and Personal: Investor Sophistication and the Disposition Effect. Management Science, 52(5), 726-740. https://doi.org/10.1287/mnsc.1040.0473

Dowie, G., \& Willows, G. (2016). An investigation of investors' estimates of returns earned and the effect of anchoring on these estimations. South African Journal of Accounting Research, 30(1), 29-40. https://doi.org/10.1080/10291954.2015.1021559

Dubra, J. (2004). Optimism and overconfidence in search. Review of Economic Dynamics, 7(1), $198-218$. https://doi.org/10.1016/S1094-2025(03)00036-X

Fama, E. F. (1970). American Finance Association Efficient Capital Markets : A Review of Theory and Empirical Work. Journal of Finance, 25(2), 28-30. https://doi.org/10.2307/2325486

Filiz, I., Nahmer, T., Spiwoks, M., \& Bizer, K. (2018). Portfolio diversification: the influence of herding, status-quo bias, and the gambler's fallacy. Financial Markets and Portfolio Management, 32(2), 167-205. https://doi.org/10.1007/s11408-018-0311-X

Glaser, M., \& Weber, M. (2010). Overconfidence. Behavioral Finance: Investors, Corporations, and Markets, 241-258.

Graham, J. R., Harvey, C. R., \& Huang, H. (2009). Investor Competence, Trading Frequency, and Home Bias. Management Science, 55(7), 1094-1106. https://doi.org/10.2139/ssrn.620801

Gruber, M. J. (1996). Another Puzzle: The Growth in Actively Managed Mutual Funds. The Journal of Finance, 51(3), 783-810. https://doi.org/10.2307/2329222

Heukelom, F. (2007). Kahneman and Tversky and the Origin of Behavioral Economics. https://doi.org/10.2139/ssrn.956887

Huang, J. B., Tan, N., \& Zhong, M. R. (2014). Incorporating overconfidence into real option decision-making model of metal mineral resources mining project. Discrete Dynamics in Nature and Society. https://doi.org/10.1155/2014/232516

Jahanmiri, M. (2018). Anchoring Bias a Criterion for Explain Profitability of 52-Weeks High and Momentum Strategies. Pacific Business Review International, 10(7), 115-124.

Jaimovich, N., \& Rebelo, S. (2007, May). Behavioral Theories of the Business Cycle. Journal Ofthe European $\begin{array}{lllll}\text { Economic Association, } & \text { 361-368. } & \text { Retrieved }\end{array}$ http://www.management4all.org/2009/11/behavioral-theories-of-motivation.html

Joo, B. A. K. (2017). Influence of Overconfidence, Optimism and Pessimism on the Rationality of the Individual Investors: An Empirical Analysis. Pacific Business Review International.

Kabasinskas, A., \& Macys, U. (2010). Calibration of bollinger bands parameters for trading strategy development in the Baltic stock Market. Engineering Economics, 21(3), 244-254. Retrieved from https://www.scopus.com/inward/record.uri?eid=2-s2.0-77954648831\&partnerID=40\&md5=9ea6d964913a1d81 84969 cf6a6c9702b

Kahneman, D., \& Tversky, A. (1979). Prospect Theory: An Analysis of Decision under Risk. Econometrica, 47(2), 263-291. https://doi.org/10.2174/138920312803582960

Kamoto, S. (2014). Impacts of internal financing on investment decisions by optimistic and overconfident managers. European Financial Management, 20(1), 107-125. https://doi.org/10.1111/j.1468-036X.2011.00624.X

Kaustia, M. (2004). Market-wide impact of the disposition effect: Evidence from IPO trading volume. Journal of Financial Markets, 7(2), 207-235. https://doi.org/10.1016/j.finmar.2003.11.002

Kaustia, M., Alho, E., \& Puttonen, V. (2008). How Much Does Expertise Reduce Behavioral Biases ? The Case of Anchoring Return Effects Estimates in Stock. Financial Management, 37(3), 391-411.

Khan, M. T. I., Tan, S. H., Chong, L. L., \& Ong, H. B. (2017). Investment characteristics, stock characteristics and portfolio diversification of finance professionals. Borsa Istanbul Review, 17(3), 164-177. https://doi.org/10.1016/j.bir.2017.04.001 
Kinoshita, K., Suzuki, K., \& Shimokawa, T. (2013). Evolutionary foundation of bounded rationality in a financial market. IEEE Transactions on Evolutionary Computation, 17(4), 528-544. https://doi.org/10.1109/TEVC.2012.2208465

Kishore. (2004, January 22-25). Theory of Behavioural Finance and its Application to Property Market: A Change in Paradigm. TTwelfth Annual Pacific Rim Real Estate Society Conference. Auckland, New Zealand.

Ko, K. J., \& James Huang, Z. (2007). Arrogance can be a virtue: Overconfidence, information acquisition, and market efficiency. Journal of Financial Economics, 84(2), 529-560. https://doi.org/10.1016/j.jfineco.2006.03.002

Krause, M., Shiller, V., Shleifer, A., Wilcox, D., \& Shiller, R. J. (1970). Human Behavior and the Efficiency of the Financial System. Handbook of Macroeconomics, 1-34.

Kumar, S., \& Goyal, N. (2015). Behavioural biases in investment decision making - a systematic literature review. Qualitative Research in Financial Markets, 7(1), 88-108. https://doi.org/10.1108/QRFM-07-2014-0022

Lee, H.-J., Park, J., Lee, J.-Y., \& Wyer, R. S. (2008). Disposition Effects and Underlying Mechanisms in E-Trading of Stocks. Journal of Marketing Research, 45(3), 362-378. https://doi.org/10.1509/jmkr.45.3.362

Lee, J. S., Yen, P. H., \& Chan, K. C. (2013). Market states and disposition effect: Evidence from Taiwan mutual fund investors. Applied Economics, 45(10), 1331-1342. https://doi.org/10.1080/00036846.2011.617696

Lin, H. (2011). Elucidating rational investment decisions and behavioral biases : Evidence from the Taiwanese stock market. African Journal of Business Management, 5(5), 1630-1631. https://doi.org/10.5897/AJBM10.474

Liu, J., Jin, X., Wang, T., \& Yuan, Y. (2015). Robust multi-period portfolio model based on prospect theory and ALMV-PSO algorithm. Expert Systems with Applications, 42(20), $7252-7262$. https://doi.org/10.1016/j.eswa.2015.04.063

Lowies, G. A., Hall, J. H., \& Cloete, C. E. (2016). Heuristic-driven bias in property investment decision-making in South Africa. Journal of Property Investment \& Finance, 34, 51-67. https://doi.org/http://dx.doi.org/10.1108/MRR-09-2015-0216

Ma, Q. Z., Wang, H., \& Zhang, W. (2017). Trading against anchoring. Review of Behavioural Finance, 9(3), 242-261. https://doi.org/http://dx.doi.org/10.1108/19405979201100005

Mello, B. A., Souza, V. M. C. S., Cajueiro, D. O., \& Andrade, R. F. S. (2010). Network evolution based on minority game with herding behavior. European Physical Journal B, 76(1), 147-156. https://doi.org/10.1140/epjb/e2010-00179-1

Mertzanis, C., \& Allam, N. (2018). Political Instability and Herding Behaviour: Evidence from Egypt's Stock Market. Journal of Emerging Market Finance, 17(1), 29-59. https://doi.org/10.1177/0972652717748087

Michael C. Jensen. (1978). Some Anomalous Evidence Regarding Market Efficiency. Journal of Financial Economics, 6, 95-101.

Mitroi, Adrian Stancu, I. (2014). Biases, Anomalies, Psychology of a Loss and Individual Investment Decision Making. Economic Computation and Economic Cybernetics Studies and Research.

Mueller, A., \& Brettel, M. (2012). Impact of biased Pecking order Preferences on firm success in real business cycles. Journal of Behavioral Finance, 13(3), 199-213. https://doi.org/10.1080/15427560.2012.708372

Musciotto, F., Marotta, L., Piilo, J., \& Mantegna, R. N. (2018). Long-term ecology of investors in a financial market. Palgrave Communications, 4(1), 92. https://doi.org/10.1057/s41599-018-0145-1

Mushinada, V. N. C., \& Veluri, V. S. S. (2018). Investors overconfidence behaviour at Bombay Stock Exchange. International Journal of Managerial Finance, 14(5), 613-632. https://doi.org/10.1108/IJMF-05-2017-0093

Niehaus, G., \& Shrider, D. (2014). Framing and the disposition effect: Evidence from mutual fund investor redemption behaviour. Quantitative Finance, 14(4), 683-697. https://doi.org/10.1080/14697688.2013.819114

Odean, T. (1999). Do investor trade too much. American Economic Review.

Odean, T., Strahilevitz, M. A., \& Barber, B. M. (2010). Once Burned, Twice Shy: How Naïve Learning, Counterfactuals, and Regret Affect the Repurchase of Stocks Previously Sold. SSRN. https://doi.org/10.2139/ssrn.611267

Ormos, M., \& Timotity, D. (2016). Unravelling the asymmetric volatility puzzle: A novel explanation of volatility through anchoring. Economic Systems, 40(3), 345-354. https://doi.org/10.1016/j.ecosys.2015.09.008 
Pelster, M., \& Hofmann, A. (2018). About the fear of reputational loss: Social trading and the disposition effect. Journal of Banking and Finance, 94, 75-88. https://doi.org/10.1016/j.jbankfin.2018.07.003

Phan, T. C., Rieger, M. O., \& Wang, M. (2018). What leads to overtrading and under-diversification? Survey evidence from retail investors in an emerging market. Journal of Behavioral and Experimental Finance, 19, 39-55. https://doi.org/10.1016/j.jbef.2018.04.001

Philippas, N., Economou, F., Babalos, V., \& Kostakis, A. (2013). Herding behavior in REITs: Novel tests and the role of financial crisis. International Review of Financial Analysis, 29, 166-174. https://doi.org/10.1016/j.irfa.2013.01.004

Prosad, J. M., Kapoor, S., Sengupta, J., \& Roychoudhary, S. (2018). Overconfidence and Disposition Effect in Indian Equity Market: An Empirical Evidence. Global Business Review, 19(5), 1303-1321. https://doi.org/10.1177/0972150917726660

Qu, C., Zhou, L., \& Luo, Y. J.. (2008). Electrophysiological correlates of adjustment process in anchoring effects. Neuroscience Letters, 445(3), 199-203. https://doi.org/10.1016/j.neulet.2008.07.061

Roger, P. (2009). Does the Consciousness of the Disposition Effect Increase the Equity Premium?. Journal of Behavioral Finance, 10(3), 138-151. https://doi.org/10.2139/ssrn.969431

Rompotis, G. G. (2018). Herding Behavior among Exchange-Traded Funds. Journal of Behavioral Finance, 19(4), 483-497. https://doi.org/10.1080/15427560.2018.1431886

Shefrin, H. (2001). Some New Evidence on Eva Companies. Journal of Applied Corporate Finance, 22(1), 32-42. https://doi.org/10.1111/j.1745-6622.1999.tb00009.x

Shefrin, H. M., \& Thaler, R. H. (1988). the Behavioral Life-Cycle Hypothesis. Economic Inquiry, 26(4), 609-643. https://doi.org/10.1111/j.1465-7295.1988.tb01520.x

Shiller, R. J. (1997). Human Behavior and the Efficiency of the Financial System.

Shin, H., \& Park, S. (2018, April). Do foreign investors mitigate anchoring bias in stock market? Evidence based on post-earnings announcement drift. Pacific Basin Finance Journal, 48, 224-240. https://doi.org/10.1016/j.pacfin.2018.02.008

Shleifer, A. (2000). Inefficient Markets. Investopedia.

Singh, S. (2016). The Role of Behavioral Finance in Modern Age Investment. Pacific Business Review International, l(1), 234-240.

Slovic, P. (1972). American Finance Association. The Journal of Finance, 72(6), 2889-2889. https://doi.org/10.1111/jofi.12597

Smit, H. T. J., \& Moraitis, T. (2010). Playing at Serial Acquisitions. California Management Review, 53(1).

Taffler, R. J., Spence, C., \& Eshraghi, A. (2017). Emotional economic man: Calculation and anxiety in fund management. Accounting, Organizations and Society, 61, 53-67. https://doi.org/10.1016/j.aos.2017.07.003

Tran, V. T., Nguyen, H., \& Lin, C. T. (2017). Herding behaviour in the Australian loan market and its impact on bank loan quality. Accounting and Finance, 57(4), 1149-1176. https://doi.org/10.1111/acfi.12183

Tversky, A., \& Kahneman, D. (1971). Belief in the law of small numbers. Psychological Bulletin, 76(2), 105-110. https://doi.org/10.1037/h0031322

Tversky, A., \& Kahneman, D. (1973). Psychological Review. American Psychological Association, 80(4). https://doi.org/10.1037/h0046234

Walters, D. J., Fernbach, P. M., Fox, C. R., \& Sloman, S. A. (2016). Known Unknowns: A Critical Determinant of Confidence and Calibration. Management Science. https://doi.org/10.1287/mnsc.2016.2580

Wright, W. F., \& Anderson, U. (1989, December). Effects of situation familiarity and financial incentives on use of the anchoring and adjustment heuristic for probability assessment. Organizational Behavior and Human Decision Processes, 44(1), 68-82. https://doi.org/10.1016/0749-5978(89)90035-6

Yu, H., Dan, M. H., Ma, Q., \& Jin, J. (2018, May). They all do it, will you? Event-related potential evidence of herding behavior in online peer-to-peer lending. Neuroscience Letters, 681, 1-5. https://doi.org/10.1016/j.neulet.2018.05.021

Zamri, A., Ibrahim, H., \& Tuyon, J. (2017). Qualitative Research in Financial Markets. Asian Review of Accounting, 181. https://doi.org/10.1108/ara.2010.34118aaa.002 